\title{
Preload Loss and Bacterial Penetration on Different Implant-Abutment Connection Systems
}

\author{
Antônio Pedro RICOMINI FILHO \\ Frederico Silva de Freitas FERNANDES \\ Fabiana Gouveia STRAIOTO \\ Wander José da SILVA \\ Altair Antoninha DEL BEL CURY
}

Department of Prosthodontics and Periodontology, Piracicaba Dental School, State University of Campinas, Piracicaba, SP, Brazil

\begin{abstract}
Preload loss can favor the occurrence of implant-abutment interface misfit, and bacterial colonization at this interface may lead to implant failure. The aim of this study was to evaluate the preload loss and bacterial penetration through the implant-abutment interface of conical and external hexagon connection systems subjected to thermal cycling and mechanical fatigue (TM). Four different implant-abutment connection systems were evaluated $(n=6)$ : external hexagon with universal post, Morse taper with universal post, Morse taper with universal post through bolt, and locking taper with standard abutment. The assemblies (implant-abutment) were subjected to a thermal cycling regimen $\left(1,000\right.$ cycles of $5^{\circ} \mathrm{C}$ and $\left.55^{\circ} \mathrm{C}\right)$ and to mechanical fatigue $(1.0 \mathrm{million}$ cycles, $1.0 \mathrm{~Hz}, 120$ $\mathrm{N})$. The assemblies were immersed in Tryptic Soy + Yeast Extract broth containing Streptococcus sanguinis and incubated at $37^{\circ} \mathrm{C}$ and $10 \% \mathrm{CO}_{2}$ for $72 \mathrm{~h}$. Detorque values were recorded. The bacterial penetration was assessed and the abutments were observed by scanning electron microscopy. The preload data were analyzed statistically by two-way ANOVA and Tukey's test at 5\% significance level. All screw abutment systems showed significantly higher $(\mathrm{p}<0.05)$ detorque values when subjected to TM and all conical systems presented bacterial penetration. The results show no relationship between the preload loss and the bacterial penetration.
\end{abstract}

Key Words: Dental implants, preload, microgap, bacterial penetration.

\section{INTRODUCTION}

Implant dentistry has become one of the most successful rehabilitation technique among medical and dental specialties. Over the last 30 years, clinical evidence has shown excellent long-term results for osseointegrated implants with success rate above $90 \%(1,2)$. However, this predictable treatment requires a dynamic equilibrium between mechanical and biological factors.

Mechanical factors, such as the implant-abutment precise fit and the abutment screw preload, are involved in the success of implant rehabilitation. The preload loss during the occlusal load with the prosthesis in function favors the misfit of the implant-abutment connection and this can result in stress increase in the implant and connection components, and consequently in the surrounding bone (3-5). Moreover, the stress at connection components could cause screw fracture and loss, abutment and prosthesis damage, requiring the repair or replacement of the prosthesis and its components.

The misfit between implants and abutment also affects the implant biological factors. The success of dental implants is first dependent on osseointegration phenomenon and late, the bone support maintenance $(2,6,7)$. The presence of a microgap at the implantabutment interface allows microorganisms to penetrate and colonize the inner part of the implant. The presence of microorganisms in the periimplant tissues may lead to a chronic inflammatory response causing implant failure. Periimplantitis can lead to implant loss in later stages $(6,8,9)$ and a correlation between biofilm accumulation and progressive periimplant bone loss has been reported in experimental and clinical studies $(6,7,10)$.

The location of the implant-abutment interface in relation to the alveolar bone has also been reported as an important role in bone loss around implants. The

Correspondence: Profa. Dra. Altair Antoninha Del Bel Cury, Departamento de Prótese e Periodontia, Faculdade de Odontologia de Piracicaba, UNICAMP, CP 52, 13414-903 Piracicaba, SP, Brasil. Tel: +55-19-2106-5294. Fax: +55-19-2106-5211. e-mail: altcury@fop.unicamp.br 
presence of an interface at the level of the alveolar bone or subcrestal is associated with a significantly higher inflammatory cell infiltrate and bone loss, as compared to the complete absence of an interface (7). Thus, alternative implant systems with different connections have been launched to the market and their main claim is that the use of the new systems can avoid periimplant tissue inflammation. Conical interfaces, as Morse taper and locking taper systems, have shown a precise fit between implant and abutment $(1,11,12)$, which could avoid bacterial penetration through the interface. In addition, these conical systems have the implant-abutment interface localized in the middle of the implant platform, different from external hexagon systems, whose interface is close to the alveolar bone $(1,9)$.

In an attempt to find an efficient bacterial seal system, several studies (11,13-17) have investigated microorganism penetration through the microgap present at implant-abutment interface, showing distinct bacterial penetration data. It should be pointed that the bacteria used in these studies have a large size, such as Escherichia coli, and facultative aerobes present in the oral cavity were not tested. In addition, these studies were performed with implant-abutment in a static condition, not considering the environmental stress present in the oral cavity. Temperature variations and occlusal loads could lead to preload loss and consequently abutment instability, modifying the implant-abutment fit, which could favor bacterial penetration in the interface. Thus, this in vitro study evaluated the preload loss and the bacterial penetration through the implant-abutment interface of conical and external hexagon connection systems, subjected to thermal cycling and mechanical fatigue.

\section{MATERIAL AND METHODS}

This in vitro study had a randomized and blinded design, using preload loss and bacterial penetration through the implant and abutment interface as dependent variables. Four different implant-abutment connection systems (Table 1) were subjected to thermal cycling and mechanical fatigue $(\mathrm{n}=6)$. The implant connections evaluated were external hexagon and two conical connections, a Morse taper with two different abutment types and a locking taper fit.

Each implant was partially embedded in epoxy resin using a silicone mold (22 mm diameter x $15 \mathrm{~mm}$ high). A dental surveyor (1000N, Bioart, São Paulo, SP, Brazil) was used to place the implant perpendicularly to the base. The implant platform was set approximately $1 \mathrm{~mm}$ above the resin level to allow the abutment connection and the bacterial penetration assay. After resin polymerization, the abutments were connected to the implants according to the manufacturers' recommendations. Each implant was rigidly held in a bench vise during the abutment tightening. The abutment screw was initially tightened with a screwdriver until the bearing surfaces of the abutment and the implant were in contact. The preload was set with a single activation with an electronic torque controller (Lutron Electronics TM 800, Taipei, Taiwan) (4). The preload of $32 \mathrm{~N} / \mathrm{cm}$ was used for external hexagon and Morse taper with universal post, and the preload of $15 \mathrm{~N} / \mathrm{cm}$ for Morse taper with universal post through bolt. The abutments of the locking taper system were seated on the implant bodies according to the manufactures' instructions.

After the abutment connection, the assemblies (implant-abutment) were subjected to 1,000 thermal cycles of $5^{\circ} \mathrm{C}$ and $55^{\circ} \mathrm{C}$ baths, with a dwell time of 60 $\mathrm{s}$ for each bath, and were then immediately placed in a mechanical fatigue machine (ERFOP 10; Erios, São Paulo, SP, Brazil). Each assembly was placed on a load cell within a parallel-type fatigue apparatus with 10 identical load cell stations. The assemblies were kept immersed in distilled water at $37^{\circ} \mathrm{C}$. The unidirectional vertical load was applied on the abutment by a pneumatic piston calibrated between 100 and $120 \mathrm{~N}$. A total of one million of loads was performed, which is equivalent to an in vivo one-year mastication period (4).

In preparation for the bacterial penetration assay,

Table 1. Implant and abutment types, dimensions and lot numbers.

\begin{tabular}{lccc}
\hline $\begin{array}{l}\text { Implant/abutment } \\
\text { type }\end{array}$ & $\begin{array}{c}\text { Diameter } \\
(\mathrm{mm})\end{array}$ & $\begin{array}{c}\text { Length } \\
(\mathrm{mm})\end{array}$ & $\begin{array}{c}\text { Lot } \\
\text { number }\end{array}$ \\
\hline $\begin{array}{l}\text { Implant type } \\
\text { External hexagon }\end{array}$ & 4 & 9 & 2764808 \\
Morse taper & 4 & 9 & 2778798 \\
Morse taper & 4 & 9 & 2778798 \\
Locking taper & 5 & 8 & $22033-0807$ \\
Abutment type & & & \\
Universal post & 4.5 & 4 & 2776406 \\
Universal post & 4.5 & 4 & 2777699 \\
Universal post through bolt & 4.5 & 4 & 2731811 \\
Non-shouldered abutment & 5.0 & 5.0 & $25170-0108$ \\
\hline
\end{tabular}


all assemblies were sterilized with ethylene oxide. The microorganism chosen for this study was Streptococcus sanguinis (NCTC 10904), a gram-positive, facultative anaerobe, pioneer colonizer of dental biofilm, which has small size (1-2 $\mu \mathrm{m}$ diameter), being capable of penetrating the implant-abutment microgap. To prepare the inoculum, $S$. sanguinis was reactivated from its original culture stored at $-70^{\circ} \mathrm{C}$, in Tryptic Soy + Yeast Extract broth (TY) (Difco Laboratories, Detroit, MI, USA) and plated on Tryptic Soy agar (Difco Laboratories). Single colonies were inoculated into $10 \mathrm{~mL}$ of TY broth and incubated at $37^{\circ} \mathrm{C}$. Cells were harvested in the late exponential growth phase by centrifugation, washed twice with phosphate buffered saline solution (PBS) (pH 7.2) and re-suspended spectrophotometrically in TY broth to a concentration of $1-5 \times 10^{5}$ cells $/ \mathrm{mL}$.

The bacterial penetration assay was performed in 12 well polystyrene culture plates. Each assembly was placed at the bottom of the well, and the inoculum media was poured in a height enough to completely cover the implant-abutment interface. The abutment could not be totally immersed in the broth because the screw hole on the top of two systems, external hexagon and Morse taper with universal post through bolt, could act as a second way for bacterial penetration. The assemblies were incubated at $37^{\circ} \mathrm{C}$ and $10 \% \mathrm{CO}_{2}$ for $72 \mathrm{~h}$. The inoculum media was changed each $12 \mathrm{~h}$. The bacterial penetration assays were performed in duplicate in three independent experiments on different days.

Each assembly was removed from the broth after the incubation period, carefully dried with sterile absorbent paper to remove the excess of broth. The implant-abutment interface was disinfected with $70 \%$ alcohol and dried with absorbent paper discs. The abutment was removed with an electronic torque controller
(Lutron Electronics TM 800) and the detorque value was recorded in $\mathrm{N} / \mathrm{cm}$. The abutments of the locking taper system were separated from the implant bodies using a forceps. A sterile paper point was rubbed on the internal implant surface to collect bacteria that had penetrated the interface. The paper point was inserted in a tube with $10 \mathrm{~mL}$ of sterile TY broth and incubated at $37^{\circ} \mathrm{C}$ and $10 \% \mathrm{CO}_{2}$ for $48 \mathrm{~h}(11,15)$. The presence of bacterial penetration was assessed by the broth turbidity. The broth that showed bacterial growth was plated on blood agar to confirm S. sanguinis by means of colony morphology and Gram staining $(11,15)$.

After the bacterial penetration assay, the implants and abutments were prepared for scanning electron microscopy (SEM) to verify bacteria presence on the implant components' surface. The components were washed with PBS twice and fixed in 2\% glutaraldehyde for $2 \mathrm{~h}$. The samples were rinsed with PBS and distilled water. Following, they were air-dried and mounted on stubs, sputter-coated with gold and examined with a scanning electron microscope (JEOL JSM-5600LV; Peabody, MA, USA) at an accelerating voltage of $15 \mathrm{kV}$.

Statistical analysis was performed using SAS software (SAS Institute Inc., version 9.0, Cary, NC, USA) with a significance level of $5 \%$. The null hypothesis assumed no difference of preload loss and bacterial penetration among the implant systems. The preload loss data was analyzed by two-way ANOVA and Tukey's test.

\section{RESULTS}

The detorque values and preload loss of the implant-abutment systems are presented in Table 2.

There were statistically significant differences in the preload loss among the systems $(\mathrm{p}<0.01)$ and inside

Table 2. Preload, detorque (mean \pm SD) and preload loss values of the implant-abutment systems.

\begin{tabular}{lccccc}
\hline Implant-abutment system & $\mathrm{n}$ & Preload (N/cm) & Detorque (N/cm) & Preload loss (\%) \\
\hline External hexagon / Universal post & 5 & 32 & $21.6 \pm 3.3$ & $-32.5^{\mathrm{A}, \mathrm{a}}$ \\
External hexagon / Universal post - TF & 6 & 32 & 32 & $29.6 \pm 3.2$ & $-23.1^{\mathrm{A}, \mathrm{b}}$ \\
Morse taper / Universal post & 5 & 32 & $36.0 \pm 1.9$ & $-9.4^{\mathrm{B}, \mathrm{a}}$ \\
Morse taper / Universal post - TF & 6 & 15 & $10.0 \pm 1.9$ & $12.5^{\mathrm{B}, \mathrm{b}}$ \\
Morse taper / Universal post through bolt & 5 & 15 & $11.5 \pm 1.0$ & $-33.3^{\mathrm{A}, \mathrm{a}}$ \\
Morse taper / Universal post through bolt - TF & 6 & $-23.3^{\mathrm{A}, \mathrm{b}}$ \\
\hline
\end{tabular}

Different uppercase letters indicate statistically significant differences among implant-abutment systems. Different lowercase letters indicate statistically significant differences between each implant-abutment system regarding thermal cycling and mechanical fatigue. 
each system $(p<0.05)$, regarding the thermal cycling and the mechanical fatigue. All systems showed higher detorque values after thermal cycling and mechanical fatigue. Morse taper connection with the universal post showed the highest detorque values and this system when subjected to thermal cycling and mechanical fatigue showed higher detorque than preload values.

The results of bacterial penetration are presented in Table 3. All the conical junction systems showed bacterial penetration independently if they were subjected to thermal cycling and mechanical fatigue, or not. The external hexagon system did not show bacterial penetration in the inner part of the implant.

Figures 1 to 4 show SEM micrographs of the implant connection systems. Only Figure 1 shows no bacterial cells on the surface of the external hexagon abutment screw, confirming the microbiological assay. Figures 2-4 (systems Morse taper with universal post, Morse taper universal post through bolt and locking ta-

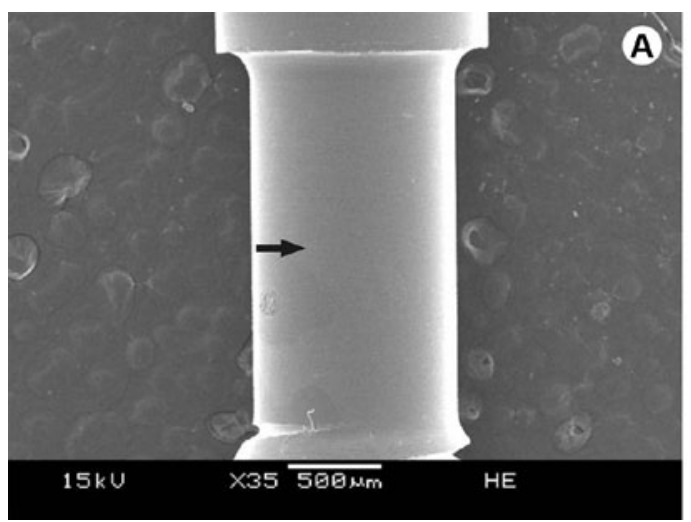

per, respectively) show bacterial penetration through the implant-abutment interface and bacterial adhesion on the abutment surface, as demonstrated by cell organization.

Table 3: Specimens in each system (percentage) that presented bacterial penetration.

\begin{tabular}{lcc}
\hline Implant-abutment system & $\mathrm{n}$ & $\begin{array}{c}\text { Bacterial } \\
\text { penetration }\end{array}$ \\
\hline External hexagon/Universal post & 5 & $0 \%$ \\
External hexagon/Universal post - TF & 6 & $0 \%$ \\
Morse taper/Universal post & 5 & $60 \%$ \\
Morse taper/Universal post - TF & 6 & $67 \%$ \\
Morse taper/Universal post through bolt & 5 & $40 \%$ \\
Morse taper/Universal post through bolt - TF & 6 & $50 \%$ \\
Locking taper/Standard & 5 & $80 \%$ \\
Locking taper/Standard - TF & 5 & $60 \%$ \\
\hline
\end{tabular}

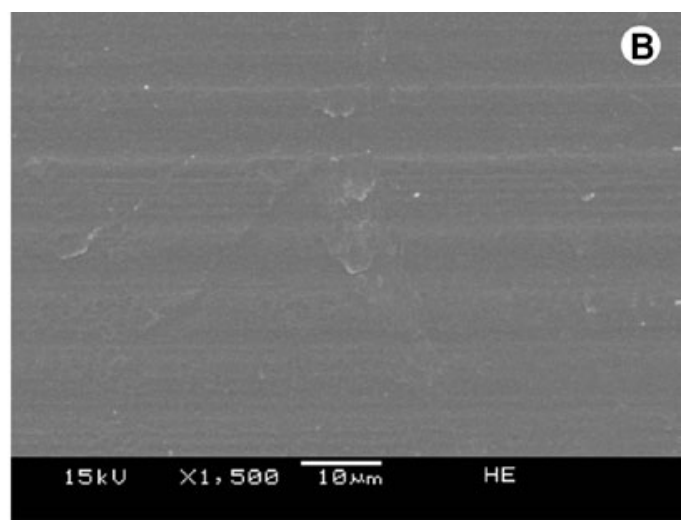

Figure 1. SEM micrograph of the external hexagon with universal post. A: Upper part the abutment screw close to the implant-abutment interface; B: Higher magnification of the area pointed by the arrow shows no bacterial growth on the surface.
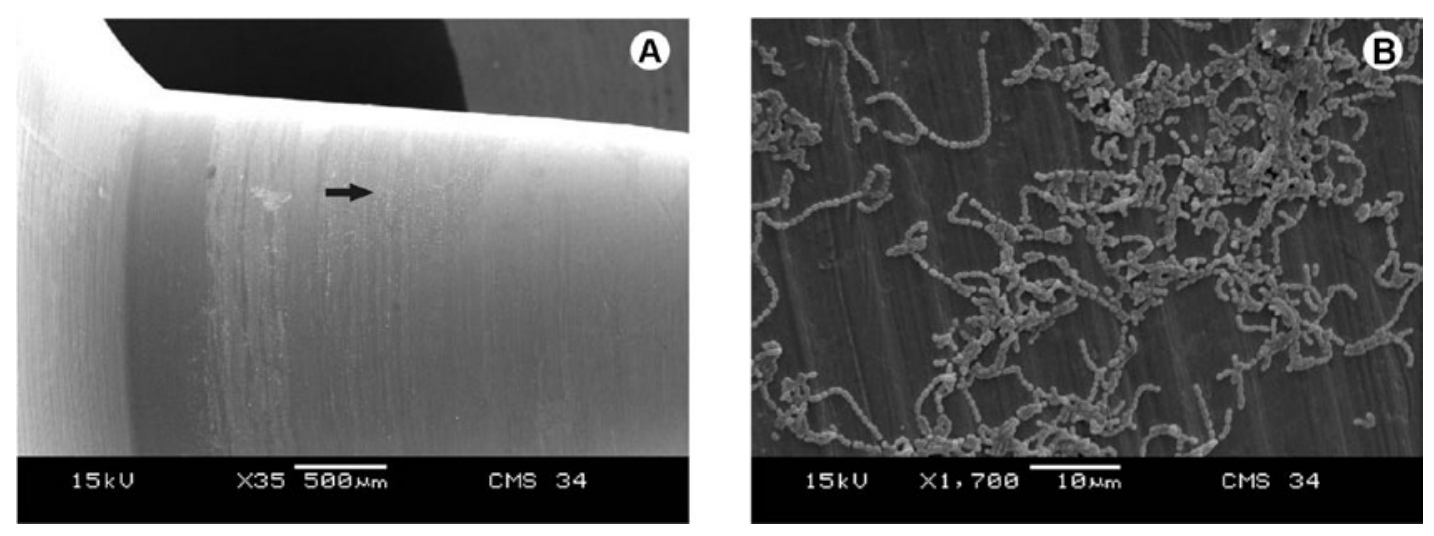

Figure 2. SEM micrograph of the Morse taper with universal post. A: Middle area of the abutment showing bacterial growth on the surface; B: Higher magnification of the area pointed by the arrow shows bacterial cells on the surface. 


\section{DISCUSSION}

Attempts to modify the implant-abutment connections have been made over the years to provide a better fit precision between implant and abutment surface in order to eliminate or decrease the interfacial microgap $(8,11,15)$. Considering the importance of the abutment stability and the bacterial penetration through the microgap, this study was performed mimicking the oral environment by subjecting the implant systems to temperature variations and mechanical loads. It was hypothesized that thermal cycling and mechanical fatigue could favor preload loss and facilitate bacterial penetration in the external hexagon and conical junction systems.

The connection between the implant-abutment surfaces depends on the screw preload applied by a predetermined amount of torque during the installation. A decrease in the detorque value has been reported when the implant system is in function over occlusal load $(3,4)$ and this data should be expected in the present study. However, all the implant systems subjected to thermal cycling and mechanical fatigue showed higher detorque values when compared to the respect system with no thermal and mechanical testing. Squier et al. (2002) evaluated the preload loss after the implant systems were subjected to thermal cycling, and no difference was observed between the cycled and non-cycled groups (18). These data associated with the higher detorque values found could suggest that the torque modification occurred because of the mechanical fatigue test. The compressive load was applied on the abutments only along the vertical axis, possibly leading to a better screw thread adjustment. In studies that found lower detorque values, the resultant load vector was not only vertical, but some lateral force was also observed, which could contribute to a great preload loss (3-5). Among the evaluated systems, the Morse taper with universal
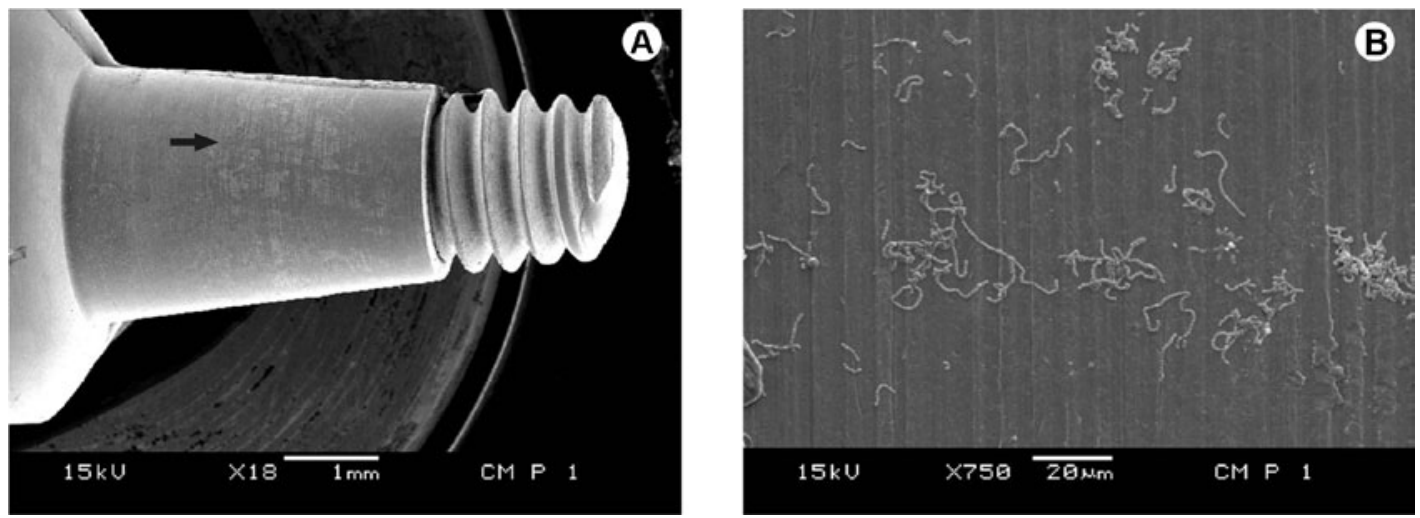

Figure 3. SEM micrograph of the Morse taper with universal post through bolt. A: Middle area of the abutment showing bacterial growth on the surface; B: Higher magnification of the area pointed by the arrow shows bacterial cells on the surface.
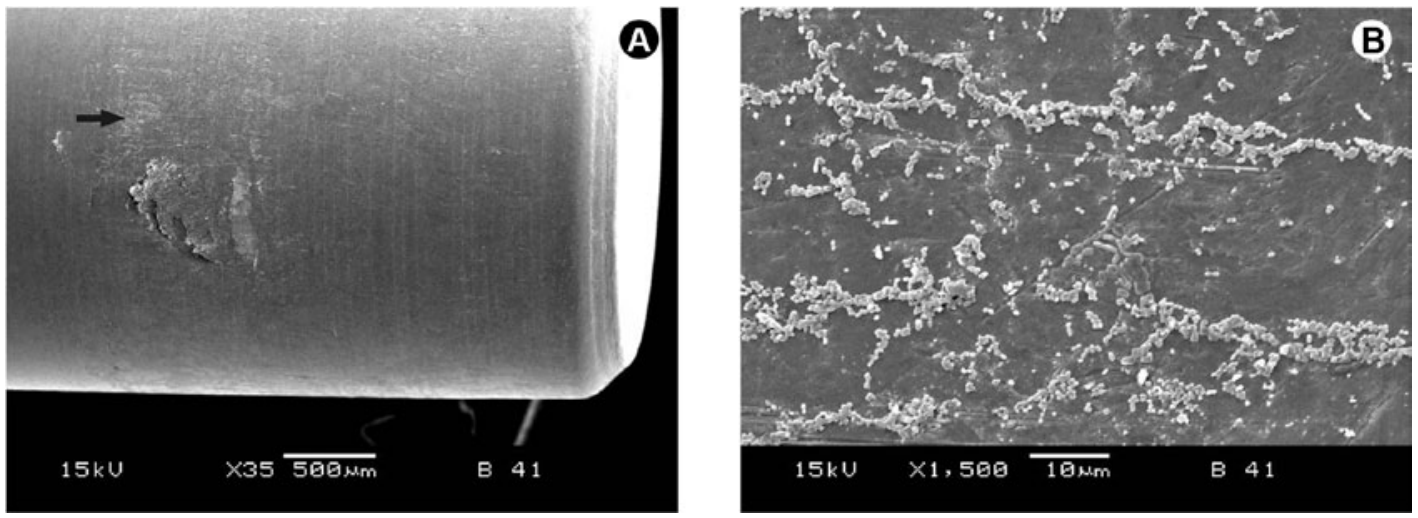

Figure 4. SEM micrograph of the Locking Taper with standard abutment. A: Middle area of the abutment showing bacterial growth on the surface; B: Higher magnification of the area pointed by the arrow shows bacterial cells on the surface. 
post showed the lowest preload loss, and it was the only system that showed higher detorque than preload after thermal cycling and mechanical fatigue. The cold welding inherent to this system favors the torque gain because of the friction between the conical abutment and the internal implant surfaces (12), which provides high stability. With higher preload loss, the system Morse taper with universal post through bolt showed similar detorque values when compared with the external hexagon system. Although Morse taper with universal post through bolt is considered a Morse taper system, its connection acts as the external hexagon because the abutment is fixed only by the screw that cross a hole in the middle of the conical abutment and a low implantabutment friction between the surfaces is present.

Although alterations in the detorque values were found, no direct relation could be established between detorque loss and bacterial penetration through the implant-abutment interface. All conical junctions, Morse taper and locking taper showed some bacterial penetration even in the assemblies with no thermal cycling or mechanical fatigue regimen. Except for the locking taper system, the findings of the present study are in accordance with those of several studies, which have shown different levels of bacterial penetration through the implant-abutment interface among the different implant systems $(13-15,19,20)$. The locking taper system has been the only conical junction reported with an efficient bacterial seal provided by the precise fit between the implant and abutment interfaces (11). However, the present results also showed bacterial penetration in the locking taper system, as confirmed by the SEM micrographs.

Although the implant-abutment interface in the external hexagon system is related to greater periimplant bone resorption compared to the conical system $(7,9)$, in the present study external hexagon system showed no bacterial penetration through the implant-abutment interface to the inner part of the implant. However, these data should be carefully reviewed. The bacterial penetration was evaluated by rubbing a paper point on the inner part of the implant in the screw hole. However, the bacterial assessment was not performed on the platform, an area next to the interface. Although the implant systems were subjected to thermal cycling and mechanical fatigue, the bacterial penetration assay was performed in a static condition. Thus, the external hexagon present on the implant platform could have acted as a physical barrier, possibly impeding that bacteria on the interface penetrated towards the inner part of the implant. This hypothesis should be evaluated in future investigations.

The results of the present study corroborate those of previous works $(11,13,15,17,19,20)$, which have shown that there is no implant connection system that provides an implant-abutment interface seal against bacterial penetration. Factors concerning the subcrestal placement of the implant-abutment interface and the distance of this interface to the surround bone should be considered on the choice of the implant-abutment connection system (7).

Within the limits of this study, it could be concluded that although the detorque values were higher after the thermal cycling and mechanical fatigue procedures, no relationship could be established with bacterial penetration through the implant-abutment interface.

\section{RESUMO}

A perda da pré-carga pode favorecer o desajuste da interface implante-pilar e a colonização bacteriana nesta interface pode levar a perda de implantes. O objetivo deste estudo foi avaliar a perda de pré-carga e a infiltração bacteriana através da interface implante-pilar de sistemas de conexão cônica e hexágono externo, submetidos à ciclagem térmica e fadiga mecânica (CF). Quatro diferentes sistemas de conexão implante-pilar foram avaliados $(n=6)$ : hexágono externo com munhão universal, cone Morse com munhão universal, cone Morse com munhão universal parafuso passante e cônica justaposição com pilar padrão. Os espécimes (implante-pilar) foram submetidos à ciclagem térmica (1000 ciclos a $5^{\circ} \mathrm{C}$ e $\left.55^{\circ} \mathrm{C}\right)$ e à fadiga mecânica $(1,0$ milhão de ciclos, 1,0 $\mathrm{Hz}, 120 \mathrm{~N})$. Os espécimes foram imersos em caldo Tryptic Soy + Yeast Extract contendo Streptococcus sanguinis e incubados a $37^{\circ} \mathrm{C}$ e $10 \%$ de $\mathrm{CO}_{2}$ por $72 \mathrm{~h}$. Os valores de destorque foram registrados. A infiltração bacteriana foi avaliada e os pilares foram observados por microscopia eletrônica de varredura. Os dados de pré-carga foram analisados estatisticamente por ANOVA a dois critérios e teste de Tukey, com nível de significância de $5 \%$. Todos os sistemas de pilares parafusados apresentaram maiores valores de destorque quando submetidos à $\mathrm{CF}(\mathrm{p}<0,05)$ e todos os sistemas cônicos apresentaram infiltração bacteriana. Os resultados mostram que não houve relação entre a perda da pré-carga e a infiltração bacteriana.

\section{ACKNOWLEDGEMENTS}

The authors thank FAPESP (2006/05552-8), from whom the first author received a Master's degree scholarship, and to the company Neodent (Curitiba, PR, Brazil) for providing the implants and components needed for this investigation.

\section{REFERENCES}

1. Mangano C, Mangano F, Piattelli A, Iezzi G, Mangano A, La Colla L. Prospective clinical evaluation of 1920 Morse taper connection 
implants: results after 4 years of functional loading. Clin Oral Implants Res 2009;20:254-261.

2. Albrektsson T. A multicenter report on osseointegrated oral implants. J Prosthet Dent 1988;60:75-84.

3. Hecker DM, Eckert SE. Cyclic loading of implant-supported prostheses: changes in component fit over time. J Prosthet Dent 2003;89:346-351.

4. Cibirka RM, Nelson SK, Lang BR, Rueggeberg FA. Examination of the implant-abutment interface after fatigue testing. J Prosthet Dent 2001;85:268-275.

5. Gratton DG, Aquilino SA, Stanford CM. Micromotion and dynamic fatigue properties of the dental implant-abutment interface. J Prosthet Dent 2001;85:47-52.

6. Oh TJ, Yoon J, Misch CE, Wang HL. The causes of early implant bone loss: myth or science? J Periodontol 2002;73:322-333.

7. Broggini N, McManus LM, Hermann JS, Medina R, Schenk RK, Buser D, et al.. Peri-implant inflammation defined by the implantabutment interface. J Dent Res 2006;85:473-478.

8. Quirynen M, De Soete M, van Steenberghe D. Infectious risks for oral implants: a review of the literature. Clin Oral Implants Res 2002;13:1-19.

9. Weng D, Nagata MJ, Bell M, Bosco AF, de Melo LG, Richter EJ. Influence of microgap location and configuration on the periimplant bone morphology in submerged implants. An experimental study in dogs. Clin Oral Implants Res 2008;19:1141-1147.

10. Berglundh T, Gotfredsen K, Zitzmann NU, Lang NP, Lindhe J. Spontaneous progression of ligature induced peri-implantitis at implants with different surface roughness: an experimental study in dogs. Clin Oral Implants Res 2007;18:655-661.

11. Dibart S, Warbington $\mathrm{M}, \mathrm{Su} \mathrm{MF}$, Skobe Z. In vitro evaluation of the implant-abutment bacterial seal: the locking taper system. Int
J Oral Maxillofac Implants 2005;20:732-737.

12. Norton MR. Assessment of cold welding properties of the internal conical interface of two commercially available implant systems. J Prosthet Dent 1999;81:159-166.

13. Gross M, Abramovich I, Weiss EI. Microleakage at the abutmentimplant interface of osseointegrated implants: a comparative study. Int J Oral Maxillofac Implants 1999;14:94-100.

14. Guindy JS, Besimo CE, Besimo R, Schiel H, Meyer J. Bacterial leakage into and from prefabricated screw-retained implant-borne crowns in vitro. J Oral Rehabil 1998;25:403-408.

15. Jansen VK, Conrads G, Richter EJ. Microbial leakage and marginal fit of the implant-abutment interface. Int J Oral Maxillofac Implants. 1997;12:527-540.

16. Persson LG, Lekholm U, Leonhardt A, Dahlen G, Lindhe J. Bacterial colonization on internal surfaces of Branemark system implant components. Clin Oral Implants Res 1996;7:90-95.

17. Quirynen M, Bollen CM, Eyssen H, van Steenberghe D. Microbial penetration along the implant components of the Branemark system. An in vitro study. Clin Oral Implants Res 1994;5:239-244

18. Squier RS, Psoter WJ, Taylor TD. Removal torques of conical, tapered implant abutments: the effects of anodization and reduction of surface area. Int J Oral Maxillofac Implants 2002;17:24-27.

19. Piattelli A, Scarano A, Paolantonio M, Assenza B, Leghissa GC Di Bonaventura $\mathrm{G}$, et al. Fluids and microbial penetration in the internal part of cement-retained versus screw-retained implantabutment connections. J Periodontol 2001;72:1146-1150.

20. Steinebrunner L, Wolfart S, Bossmann K, Kern M. In vitro evaluation of bacterial leakage along the implant-abutment interface of different implant systems. Int J Oral Maxillofac Implants $2005 ; 20: 875-881$.

Accepted April 20, 2010 